\title{
Perkembangan Diagnosis Sepsis pada Anak
}

Anindita Wulandari, Sri Martuti, Pudjiastuti

Departemen Ilmu Kesehatan Anak Fakultas Kedokteran Universitas Sebelas Maret/RS dr. Moewardi Surakarta

Sepsis merupakan salah satu penyebab utama morbiditas dan mortalitas bayi dan anak di seluruh dunia. Sepsis awalnya didefinisikan sebagai kecurigaan atau infeksi yang terbukti, disertai kondisi klinis SIRS (systemic inflammatory response syndrome), tetapi definisi tersebut kini ditinggalkan. Sesuai konsensus mengenai sepsis terbaru, sepsis didefinisikan sebagai keadaan disfungsi/gagal organ yang mengancam nyawa, disebabkan oleh respon pejamu yang tidak teregulasi terhadap infeksi. Penilaian disfungsi/gagal organ pada anak menggunakan beberapa sistem penilaian, antara lain, Pediatric Multiple Organ Dysfunction Score (P-MODS), Pediatric Logistic Organ Dysfunction (PELOD), Pediatric Logistic Organ Dysfunction-2 (PELOD-2), dan pada konsensus terbaru diperkenalkannya sistem Pediatric Sequential Organ Failure Assessment (pSOFA) yang diadaptasi dari sistem Sequential Organ Failure Assessment (SOFA) dengan hasil validasi menunjukkan bahwa pSOFA memberikan hasil yang sama baik dengan sistem penilaian yang lain. Di Indonesia saat ini, PELOD-2 merupakan sistem penilaian disfungsi organ yang direkomendasikan oleh Ikatan Dokter Anak Indonesia (IDAI) dalam mendiagnosis sepsis pada anak. Sari Pediatri 2017;19(4):237-44

Kata kunci: sepsis, disfungsi organ, PELOD-2, SOFA, anak

\section{Diagnosis of Sepsis in Children Recently}

Anindita Wulandari, Sri Martuti, Pudjiastuti

Sepsis remains a major cause of morbidity and mortality among infants and children around the world. Sepsis was originally defined as a suspected or proven infection, accompanied by a SIRS (systemic inflammatory response syndrome) condition. But the definition is now being revised. In accordance with the latest consensus sepsis, sepsis is defined as a life-threatening organ dysfunction/failure condition, caused by dysregulated host response to infection. Assessment of organ dysfunction in children may use some scoring systems, including Pediatric Multiple Organ Dysfunction Score (P-MODS), Pediatric Logistic Organ Dysfunction (PELOD), Pediatric Logistic Organ Dysfunction-2 (PELOD-2), and recent consensus introducing the Pediatric Sequential Organ Failure Assessment (pSOFA) systems adapted from the SOFA system, with validation results showing that pSOFA deliver results as well as other organ dysfunction scoring systems. In Indonesia, PELOD-2 is the scoring system of organ dysfunction recommended by the Indonesian Pediatric Association (IDAI) in diagnosing sepsis in children. Sari Pediatri 2017;19(4):237-44

Keyword: sepsis, organ dysfunction, SOFA, PELOD-2, children

Alamat korespondensi: Dr. Anindita Wulandari. Departemen Ilmu Kesehatan Anak Fakultas Kedokteran Universitas Sebelas Maret / RS dr. Moewardi Surakarta. Email: ilmiah.anin@gmail.com 
S epsis masih menjadi masalah kesehatan yang harus diwaspadai dan merupakan salah satu penyebab utama morbiditas dan mortalitas bayi dan anak di seluruh dunia. Beberapa faktor yang berperan terhadap mortalitas sepsis pada anak meliputi faktor pejamu, mikroorganisme penyebab, diagnosis dini, serta tata laksana yang diberikan. Hingga saat ini biomarker tunggal yang dapat menegakkan diagnosis sepsis belum ada sehingga upaya untuk memperbaiki kriteria diagnosis masih terus dilakukan. Selanjutnya, para klinisi dapat memberi tata laksana adekuat pada pasien. Kriteria diagnosis sepsis pada anak memerlukan beberapa penyesuaian dari kriteria pada pasien dewasa, terkait dengan perbedaan fisiologi pada anak dan dewasa. ${ }^{1-3}$

\section{Epidemiologi}

Kejadian sepsis secara signifikan lebih tinggi pada kelompok umur yang lebih muda dan anak dengan komorbiditas yang mengakibatkan keadaan defisiensi imunitas, seperti keganasan, transplantasi, penyakit kronis, dan kelainan jantung bawaan. Penyebab infeksi tersering sepsis pada anak, yaitu infeksi saluran pernapasan, diikuti dengan infeksi non-spesifik, bakteremia, infeksi saluran kemih, infeksi saluran pencernaan, infeksi sistem saraf pusat, dan lainnya. Infeksi luka operasi dan jaringan lunak juga dapat menyebabkan sepsis pada anak..$^{2-4}$

Sebuah studi prevalensi internasional tahun 2015 yang mengumpulkan data dari 26 negara didapatkan prevalensi global sepsis pada unit perawatan intensif anak $8,2 \%$. Rerata usia sepsis adalah 3 tahun dan infeksi terbanyak terdapat pada sistem respirasi (40\%). Hal yang sama didapatkan di Indonesia. Sebagian besar sumber infeksi berasal dari infeksi saluran pernapasan (36\% - 42\%) dengan insiden sepsis lebih tinggi pada kelompok neonatus dan bayi $<1$ tahun dibandingkan dengan usia 1-18 tahun (9,7:0,23 kasus per 1000 anak). ${ }^{3,5}$

\section{Etiologi}

Sepsis disebabkan oleh respon imunitas yang dipicu oleh infeksi bakteri, jamur, parasit atau virus. Infeksi dapat berasal dari dalam rumah sakit (nosokomial), atau lingkungan (community acquired). Data dari beberapa studi memperlihatkan mikroorganisme penyebab infeksi tersering adalah Staphylococcus, diikuti oleh Streptococcus dan infeksi jamur, terutama spesies Candida. ${ }^{6}$

\section{Patofisiologi}

Sepsis menggambarkan suatu sindrom klinis kompleks yang timbul saat sistem imunitas pejamu teraktifasi terhadap infeksi. Molekul patogen mengaktifkan sistem kekebalan tubuh, melepaskan mediator inflamasi dan memicu pelepasan sitokin yang penting dalam eliminasi patogen. Sitokin proinflamasi, seperti TNF, IL-1, interferon gamma (IFN- $\gamma$ ) bekerja membantu sel dalam menghancurkan mikroorganisme yang menginfeksi. Dengan demikian, proses eliminasi lebih efektif, sekaligus memicu pelepasan sitokin anti inflamasi, seperti interleukin-1 receptor antagonis (IL-1 ra), IL-4, dan IL-10. Sitokin anti inflamasi berperan menghentikan proses inflamasi dengan memodulasi, koordinasi, atau represi terhadap respon yang berlebihan (mekanisme umpan balik). Sitokin pro-inflamasi juga berperan dalam pelepasan nitrogen monoksida (nitric oxide, NO) yang penting dalam eliminasi patogen, tetapi efek NO lainnya adalah vasodilatasi vaskuler. Pada keadaan sepsis, produksi NO yang berlebih menyebabkan dilatasi pembuluh darah dan menyebabkan syok septik. ${ }^{7,8}$

Ketika sistem imun tidak efektif mengeliminasi antigen, proses inflamasi menjadi tidak terkendali dan menyebabkan kegagalan sistem organ. Hal tersebut sesuai dengan penelitian yang dilakukan Bone ${ }^{9}$ yang menyatakan bahwa kerusakan organ multipel tidak disebabkan oleh infeksi tetapi akibat dari inflamasi sistemik dengan sitokin sebagai mediator.

\section{Sejarah}

Sepsis sudah dikenal sejak dulu sebagai keadaan dengan keberadaan bakteri. Hippocrates mendefinisikan sepsis sebagai suatu pembusukan biologis internal berbahaya yang terjadi pada tubuh. Perkembangan medis dan teori kuman pada akhir 1800-an oleh Louis Pasteur, Joseph Lister, dan Robert Kock mengubah sudut pandang sepsis dari pembusukan internal menjadi suatu proses yang yang berasal dari mikroorganisme berbahaya. Kemudian pada tahun 1914, Hugo 
Schottmüller membuat definisi sepsis modern pada tulisannya, "Sepsis adalah keadaan dimana bakteri patogen, secara terus-menerus atau berkala, menyerang aliran darah sedemikian rupa sehingga menyebabkan gejala subyektif dan obyektif". ${ }^{10}$

\section{Sepsis pada tahun 1992-2001}

Kurangnya konsensus mengenai definisi sepsis menyebabkan kesulitan dalam diagnosis serta tata laksana terhadap pasien. Maka pada tahun 1992 diadakan sebuah konferensi internasional oleh Society of Critical Care Medicine (SCCM) dan American College of Chest Physicians (ACCP)mengenai sepsis yang pertama. Konferensi tersebut memperkenalkan istilah SIRS (systemic inflammatory response syndrome), sepsis berat (severe sepsis), dan syok septik (septic shock). Systemic inflammatory response syndrom merupakan sindron respon inflamasi sitemik yang ditandai oleh 4 indikator, yaitu kelainan suhu, frekuensi denyut jantung, frekuensi napas, dan jumlah sel darah putih.

Konferensi ini menetapkan definisi sepsis, yaitu keadaan SIRS pada kecurigaan atau infeksi yang terbukti. Sepsis berat adalah sepsis yang berhubungan dengan disfungsi organ, hipoperfusi, atau hipotensi. Syok septik adalah hipotensi yang menetap pada sepsis meskipun sudah diberikan tata laksana cairan yang adekuat. ${ }^{11}$

\section{Sepsis pada tahun 2001-2015}

Pada tahun 2001 diadakan konferensi sepsis yang kedua untuk meninjau kemajuan klinis yang dibuat dalam diagnosis dan tata laksana sepsis. Dihasilkan beberapa rekomendasi, antara lain, definisi sepsis, sepsis berat dan syok septik tetap digunakan sesuai konsensus sebelumnya. Selain itu juga diperkenalkan sistem PIRO (predisposition, infection, response, organ dysfunction) dalam pendekatan diagnosis sepsis. Sejak saat itu beberapa sistem penilaian dikembangkan dalam menentukan adanya disfungsi organ, beratnya penyakit, dan memerkirakan risiko mortalitas pada pasien sakit kritis. Selain itu, keadaran akan sepsis di antara tenaga medis dan masyarakat juga semakin meningkat, termasuk peluncuran hari sepsis dunia yaitu tanggal 13 September. ${ }^{12-14}$

Hingga konsensus sepsis yang kedua, definisi sepsis pada anak masih mengikuti kriteria untuk

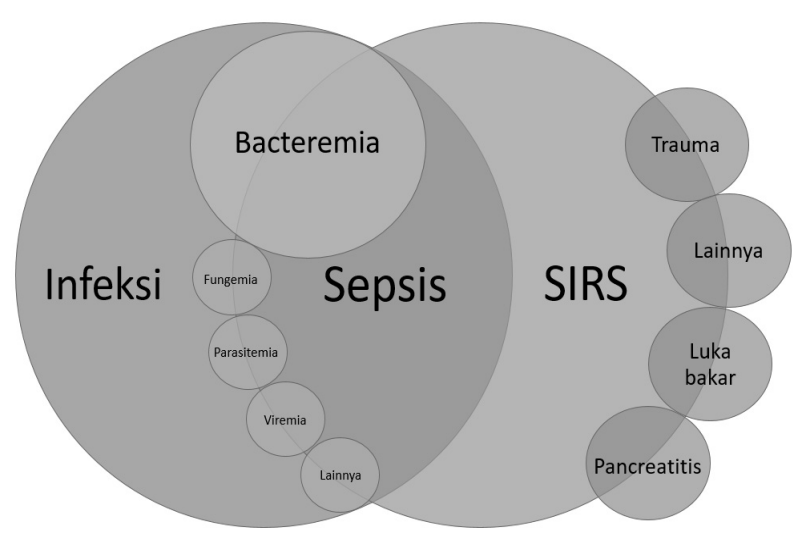

Gambar 1. Konsep infeksi, SIRS, Sepsis diperkenalkan pada konferensi sepsis tahun $1992^{11}$

pasien dewasa. Namun, tidak adanya definisi standar untuk sepsis pada anak mengakibatkan keseragaman global mengenai sepsis pada anak kurang sehingga berpengaruh pada diagnosis dan tata laksananya. Kemudian pada tahun 2005, Pediatric Sepsis Consensus Congress (PSCC) membakukan definisi sepsis pada anak, dengan pertimbangan dan modifikasi terkait fisiologi dan tanda vital yang spesifik sesuai usia. ${ }^{15}$

\section{Sepsis tahun 2016 - sekarang}

Ikatan Dokter Anak Indonesia memublikasi pedoman nasional diagnosis dan tata laksana sepsis anak pada tahun 2016. Berdasarkan pedoman tersebut, diagnosis sepsis ditegakkan berdasarkan adanya (1) infeksi, yang meliputi faktor predisposisi infeksi, tanda atau bukti infeksi yang sedang berlangsung, dan respon inflamasi; (2) tanda disfugsi / gagal organ.

Kecurigaan infeksi didasarkan pada predisposisi infeksi, tanda infeksi, dan reaksi inflamasi. Faktor predisposisi infeksi, antara lain, faktor genetik, usia, status nutrisi, status imunisasi, komorbiditas, dan riwayat terapi. Tanda klinis infeksi dinilai dari pemeriksaan klinis dan laboratoris dengan penanda (biomarker) infeksi, seperti pemeriksaan darah tepi, morfologi darah tepi, c-reactive protein, dan prokalsitonin. Respon inflamasi dapat terjadi tidak hanya disebabkan oleh penyakit infeksi. Secara klinis respon inflamasi dapat berupa :

- Demam (suhu inti $>38,5^{\circ} \mathrm{C}$ atau suhu aksila $>37,9^{\circ} \mathrm{C}$ ) atau hipotermia (suhu inti $<36^{\circ} \mathrm{C}$ )

- Takikardia (peningkatan denyut jantung sesuai usia tanpa adanya stimulus eksternal, obat kronis, atau 
nyeri; atau peningkatan denyut jantung yang tidak dapat dijelaskan lebih dari 0,5 sampai 4 jam).

- Bradikardia (penurunan denyut jantung sesuai usia tanpa adanya stimulus vagal eksternal, beta-blocker, atau penyakit jantung kongenital; atau penurunan denyut jantung yang tidak dapat dijelaskan selama lebih dari 0,5 jam).

- Takipneu: peningkatan frekuensi napas.

Disfungsi organ meliputi sistem kardiovaskular, respirasi, hematologi, sistem saraf pusat, dan hepatik. Disfungsi organ ditegakkan berdasarkan skor pediatric

Tabel 1. Definisi sepsis pada anak (The International Consensus Conference on Pediatric Sepsis, 2005) ${ }^{15}$

\section{Infeksi}

Diduga atau terbukti terinfeksi patogen apapun atau sindrom klinis terkait dengan kemungkinan infeksi

Sindrom respon inflamasi sistemik (SIRS/Systemic inflammatory response syndrome)

Respon inflamasi umum, yang didefinisikan oleh adanya $\geq 2$ dari kriteria berikut (suhu atau jumlah sel darah putih abnormal harus terpenuhi pada salah satu kriteria):

- Suhu inti tidak normal $\left(<36{ }^{\circ} \mathrm{C}\right.$ atau $\left.>38,5^{\circ} \mathrm{C}\right)$

- Laju nadi abnormal ( $>2$ standar deviasi di atas normal untuk usia, atau $<$ p10 untuk usia jika anak berusia $<1$ tahun)

- Laju napas meningkat (>2 SD untuk usia, atau penggunaan ventilasi mekanis pada penyakit paru akut)

- Jumlah sel darah putih abnormal (sesuai usia) atau $>10 \%$ leukosit imatur

\section{Sepsis}

SIRS dengan adanya infeksi

\section{Sepsis berat}

Sepsis yang disertai dengan adanya salah satu dari:

- Disfungsi kardiovaskular

- Sindrom distres pernafasan akut

- Disfungsi $\geq 2$ sistem organ

\section{Syok septik}

Sepsis dengan disfungsi kardiovaskular berlangsung setelah pemberian resusitasi cairan

\section{Syok septik refrakter}

Syok septik refrakter cairan - syok menetap setelah pemberian cairan resusitasi sebanyak $60 \mathrm{cc} / \mathrm{kgBB}$

Syok septik refrakter katekolamin - syok menetap dengan pemberian terapi katekolamin

\section{Sepsis pada neonatus}

didefinisikan sebagai sindrom klinis sepsis atau isolasi patogen di aliran darah, atau keduanya, pada bayi pada 28 hari pertama kehidupan. Sepsis pada bayi baru lahir diklasifikasikan sesuai onset dalam kaitannya dengan kelahiran:

- Sepsis neonatus onset awal : sepsis yang timbul sebelum 72 jam awal kehidupan

- Sepsis neonatus onset lanjut : sepsis yang timbul setelah 72 jam awal kehidupan

\section{Klasifikasi sesuai usia :}

Untuk tujuan konsistensi dalam klasifikasi, kelompok usia berikut digunakan untuk referensi kisaran normal variabel fisiologis dan nilai laboratorium:

$\begin{array}{ll}\text { Baru lahir } & : 0 \text { hari sampai } 1 \text { minggu } \\ \text { Neonate } & : 0 \text { hari sampai } 1 \text { bulan } \\ \text { Bayi } & : 1 \text { bulan sampai }<2 \text { tahun } \\ \text { Balita dan prasekolah } & : \geq 2 \text { tahun sampai }<6 \text { tahun } \\ \text { Anak usia sekolah } & : \geq 6 \text { tahun sampai }<13 \text { tahun } \\ \text { Remaja dan dewasa muda } & : \geq 13 \text { tahun sampai }<18 \text { tahun. }\end{array}$


logistic organ dysfunction-2 (PELOD-2). Diagnosis sepsis ditegakkan bila skor PELOD-2 $\geq 11$ (pada rumah sakit tipe A), atau $\geq 7$ pada layanan kesehatan tipe B atau C. ${ }^{5}$

Skor pediatric logistic organ dysfunction (PELOD) adalah sistem penilaian deskriptif yang digunakan untuk mengetahui adanya disfungsi/gagal organ, dan keparahan penyakit pada anak sakit kritis. Rancangan PELOD-2 untuk memperbarui dan memperbaiki PELOD. Perubahan yang dilakukan adalah penambahan tekanan arteri rata-rata dan laktatemia pada disfungsi kardiovaskular yang dinilai juga pada skor SOFA dan P-MODS. Di sisi lain, PELOD-2 tidak termasuk disfungsi hepar, yang merupakan bagian dari versi pertama PELOD. ${ }^{16,17}$

Sementara itu di tahun yang sama 2016, Society of Critical Care Medicine (SCCM) dan European Society of Intensive Care Medicine (ESICM) mengadakan konferensi ketiga yang membahas mengenai sepsis secara global. Pada pertemuan ini diusulkan sebuah definisi baru. Sepsis didefinisikan sebagai suatu keadaan disfungsi organ yang mengancam nyawa disebabkan oleh respon pejamu (pasien) yang tidak teregulasi terhadap infeksi. Definisi baru ini meninggalkan penggunaan kriteria systemic inflammatory response syndrome (SIRS) dalam identifikasi sepsis, dan tahap klinis yang sebelumnya dikenal dengan sepsis berat (severe sepsis). Pada konsensus terbaru ini digunakan dalam mendefinisikan sepsis. ${ }^{18}$

Terminologi syok septik (septic shock) tetap digunakan dan didefinisikan sebagai kelainan sirkulasi, seluler dan metabolik yang cukup besar serta meningkatkan risiko kematian. Keadaan syok septik ditandai dengan keadaan klinis sepsis dengan hipotensi menetap yang memerlukan vasopresor untuk mempertahankan MAP $\geq 65 \mathrm{mmHg}$ dan memiliki tingkat laktat serum $>2 \mathrm{mmol} / \mathrm{L}(18 \mathrm{mg} / \mathrm{dL})$ meskipun sudah diberikan resusitasi volume yang adekuat. ${ }^{18}$

Sebagai bagian dari kriteria 2016 untuk mengidentifikasi pasien sepsis, satuan tugas juga membandingkan kriteria SIRS tradisional dengan metode lain, termasuk penilaian disfungsi organ dengan logistic organ dysfunction system (LODS) dan sequential organ failure assestment (SOFA). Dilakukan validasi skor SOFA pada pasien dewasa dengan dugaan infeksi dan ditemukan bahwa sistem SOFA sebanding, bahkan lebih unggul dari sistem penilaian lainnya dalam menilai terjadinya disfungsi organ serta membedakan mortalitas di rumah sakit. Di antara pasien kritis dengan dugaan sepsis, validitas prediktif skor SOFA untuk mortalitas di rumah sakit lebih tinggi dari kriteria SIRS (area di bawah kurva ROC 0,74 berbanding 0,64 ). Pasien dengan skor SOFA $\geq 2$ memiliki prediksi angka kematian $\geq 10 \%$. Meskipun kapasitas prediksi SOFA dan LODS serupa, SOFA dianggap lebih mudah dihitung. Oleh karena itu, SOFA direkomendasikan untuk menilai disfungsi organ. Peneliti lain telah mendukung gagasan bahwa SIRS bukanlah penanda ideal untuk sepsis. Kaukonen dkk $^{19}$ mengevaluasi adanya kriteria SIRS pada 109.663 pasien dengan infeksi dan kegagalan organ. Dalam penelitian ini, $12 \%$ pasien diklasifikasikan sebagai sepsis SIRS-negatif (yaitu kriteria SIRS <2). Selain itu, kriteria SIRS ada di banyak pasien rawat inap, termasuk mereka yang tidak pernah mengalami infeksi.

Sequential organ failure assessment (SOFA) dipilih sebagai sistem penilaian untuk mengukur disfungsi

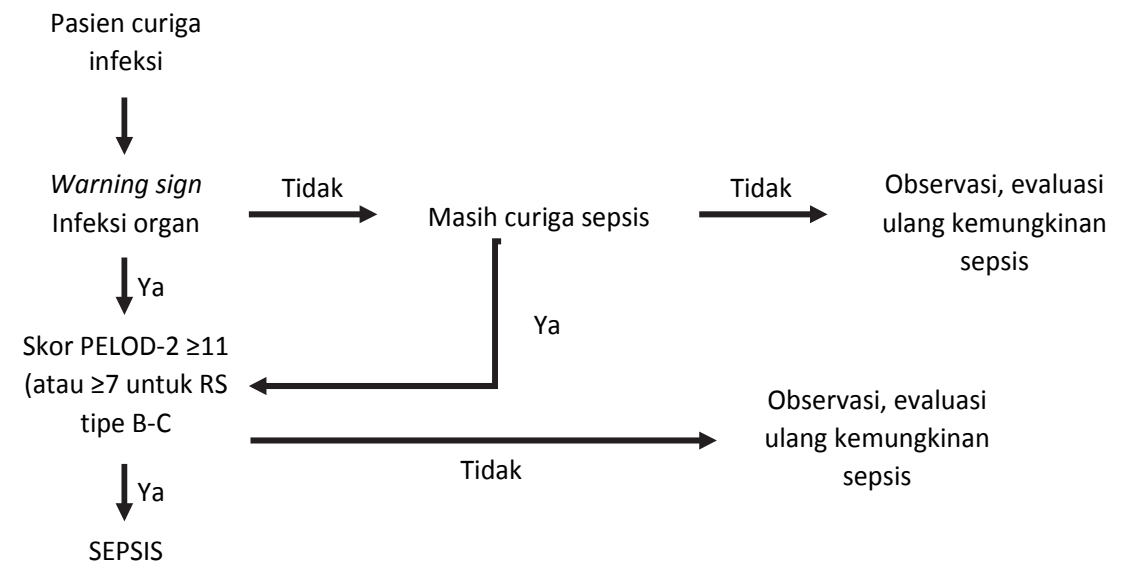

Gambar 2. Alur penegakan diagnosis sepsis - Pedoman Nasional IDAI $2016^{5}$ 
organ dalam konsensus terbaru. Definisi terbaru ini diharapkan dapat dipergunakan secara luas dengan penggunaan skor SOFA pada pasien dengan kecurigaan atau terbukti infeksi. Terkait dengan definisi baru sesuai rekomendasi konsensus internasional tersebut, satuan tugas kemudian lebih lanjut melakukan penyesuaian skor SOFA untuk pasien anak dengan sepsis sehingga menghasilkan pediatric sequential organ failure assessment (pSOFA). Skor pediatric-SOFA dibuat dari skor SOFA pada pasien dewasa dengan penyesuaian untuk sistem kardiovaskular dan renal sesuai usia, diadaptasi dari skor PELOD-2. ${ }^{20}$

Gogia $\mathrm{dkk}^{21}$ melakukan studi terhadap skor SOFA dan PELOD dalam menilai prognosis dan memprediksi kematian pada pasien anak sakit kritis di ruang rawat intensif anak di India. Dari penelitian tersebut diperlihatkan bahwa sistem penilaian SOFA pada 72 jam perawatan secara statistik berhubungan dengan prognosis dalam memprediksi mortalitas, sama baik dengan sistem PELOD, dengan sensitifitas $96 \%$, spesifisitas $98 \%$, positif predictive value $90 \%$, dan negative predictive value $99 \%$.

Tabel 2. Pediatric-logistic organ dysfunction-2 (PELOD-2) score $e^{5}$

\begin{tabular}{|c|c|c|c|c|c|c|c|}
\hline \multirow[t]{2}{*}{ Disfungsi organ dan variabel } & \multicolumn{7}{|c|}{ Poin berdasarkan tingkat keparahan } \\
\hline & 0 & 1 & 2 & 3 & 4 & 5 & 6 \\
\hline \multicolumn{8}{|l|}{ Neurologi } \\
\hline Glasglow Coma Score & $\geq 11$ & $5-10$ & & & $3-4$ & & \\
\hline Pupillary reaction & $\begin{array}{c}\text { Keduanya } \\
\text { reaktif }\end{array}$ & & & & \multicolumn{3}{|c|}{$\begin{array}{c}\text { Kedua- } \\
\text { nya tidak } \\
\text { reaktif }\end{array}$} \\
\hline \multicolumn{8}{|l|}{ Kardiologi } \\
\hline Laktatemia (mmol/L) & $<5.0$ & $5.0-10.9$ & & & $\geq 11.0$ & & \\
\hline \multicolumn{8}{|l|}{ Mean Arterial Preassure (mmHg) } \\
\hline $0-<1$ bulan & $\geq 46$ & & $31-45$ & $17-30$ & & & $\leq 16$ \\
\hline $1-11$ bulan & $\geq 55$ & & $39-54$ & $25-38$ & & & $\leq 24$ \\
\hline 12-23 bulan & $\geq 60$ & & $44-59$ & $31-43$ & & & $\leq 30$ \\
\hline $24-59$ bulan & $\geq 62$ & & $46-61$ & $32-44$ & & & $\leq 31$ \\
\hline $60-143$ bulan & $\geq 65$ & & $49-64$ & $36-48$ & & & $\leq 35$ \\
\hline$\geq 144$ bulan & $\geq 67$ & & $52-68$ & $38-51$ & & & $\leq 37$ \\
\hline \multicolumn{8}{|l|}{ Renal } \\
\hline \multicolumn{8}{|l|}{ Kreatinin $(\mu \mathrm{mol} / \mathrm{L})$} \\
\hline $0-<1$ bulan & $\leq 69$ & & $\geq 70$ & & & & \\
\hline $1-11$ bulan & $\leq 22$ & & $\geq 23$ & & & & \\
\hline $12-23$ bulan & $\leq 34$ & & $\geq 35$ & & & & \\
\hline 24-59 bulan & $\leq 50$ & & $\geq 51$ & & & & \\
\hline 60-143 bulan & $\leq 58$ & & $\geq 59$ & & & & \\
\hline$\geq 144$ bulan & $\leq 92$ & & $\geq 93$ & & & & \\
\hline \multicolumn{8}{|l|}{ Respiratori } \\
\hline $\mathrm{PaO} 2(\mathrm{mmHg}) / \mathrm{FiO} 2$ & $\geq$ & & $\leq 60$ & & & & \\
\hline $\mathrm{PaCO} 2(\mathrm{mmHg})$ & $\leq$ & & & $\geq 95$ & & & \\
\hline Ventilasi invasif & tidak & $59-94$ & & ya & & & \\
\hline \multicolumn{8}{|l|}{ Hematologi } \\
\hline Hitung sel darah & $>2$ & & $\leq 2$ & & & & \\
\hline \multicolumn{8}{|l|}{ Putih (x 10\%/L) } \\
\hline Platelet (x 109/L) & $\geq 142$ & $77-141$ & $\leq 76$ & & & & \\
\hline
\end{tabular}


Matics $\mathrm{dkk}^{20}$ melakukan adaptasi serta validasi terhadap skor pSOFA. Penelitian tersebut membandingkan pSOFA dengan sistem penilaian disfungsi organ lainnya, seperti PELOD, PELOD-2, dan pediatric multiple organ dysfunction (PMODS). Serta evaluasi klinis dari komponen pSOFA, dibandingkan

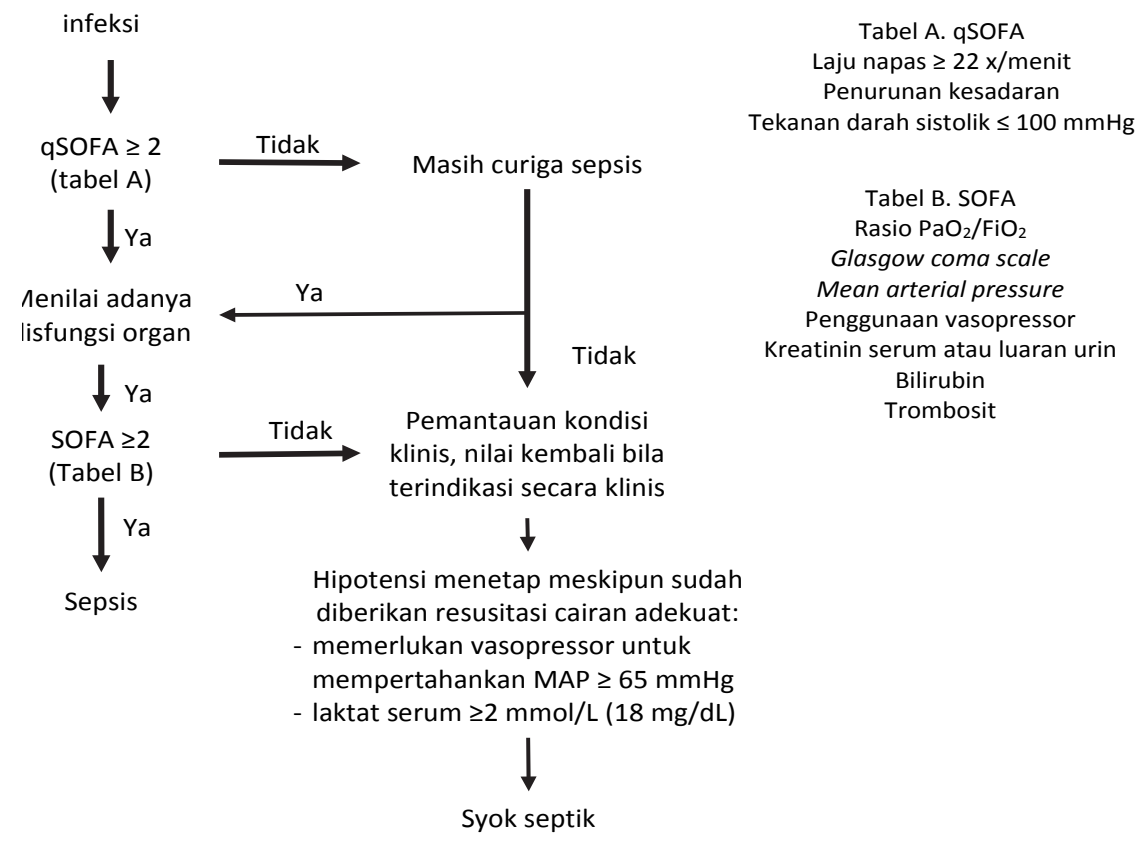

Gambar 3. Alur penegakan diagnosis sepsis - The third international consensus definitions for sepsis and shock septic, $2016^{18}$

Tabel 3. Pediatric sequential organ failure assestment (P-SOFA) score ${ }^{20}$

\begin{tabular}{|c|c|c|c|c|c|}
\hline \multirow[t]{2}{*}{ System } & \multicolumn{5}{|c|}{ Score } \\
\hline & 0 & 1 & 2 & 3 & 4 \\
\hline \multicolumn{6}{|l|}{ Respiration } \\
\hline $\mathrm{PaO}_{2} / \mathrm{Fio}_{2} \mathrm{mmHg}(\mathrm{kPa})$ & $\geq 400(53.3)$ & $<400(53.3)$ & $<300(40)$ & $\begin{array}{l}<200(26.7) \text { with } \\
\text { respiratory support }\end{array}$ & $\begin{array}{l}<100 \text { (13.3) with } \\
\text { respiratory support }\end{array}$ \\
\hline \multicolumn{6}{|l|}{ Coagulation } \\
\hline Platelets, $\times 10^{3} / \mu \mathrm{L}$ & $\geq 150$ & $<150$ & $<100$ & $<50$ & $<20$ \\
\hline $\begin{array}{l}\text { Liver } \\
\text { Bilirubin, mg/dL } \\
(\mu \mathrm{mol} / \mathrm{L})\end{array}$ & $<1.2(20)$ & $\begin{array}{l}1.2-1.9(20- \\
32)\end{array}$ & $2.0-59(33-101)$ & $6.0-11.9(102-204)$ & $>12.0(204)$ \\
\hline Cardiovascular & $\begin{array}{c}\mathrm{MAP} \geq 70 \\
\mathrm{mmHg}\end{array}$ & $\begin{array}{c}\mathrm{MAP}<70 \\
\mathrm{mmHg}\end{array}$ & $\begin{array}{c}\text { Dopamine }<5 \text { or } \\
\text { dobutamine (any } \\
\text { dose) }\end{array}$ & $\begin{array}{c}\text { Dopamine } 5.1-15 \\
\text { or epinephrine } \leq 0.1 \\
\text { or norephinephrine } \\
\leq 0.1^{\mathrm{b}}\end{array}$ & $\begin{array}{c}\text { Dopamine }>15 \\
\text { or epinephrine }>0.1 \\
\text { or norephinephrine } \\
>0.1^{\mathrm{b}}\end{array}$ \\
\hline \multicolumn{6}{|l|}{ Central Nervous System } \\
\hline $\begin{array}{l}\text { Glasgow Coma Scale } \\
\text { score }\end{array}$ & 15 & $13-14$ & $10-12$ & $6-9$ & $<6$ \\
\hline \multicolumn{6}{|l|}{ Renal } \\
\hline $\begin{array}{l}\text { Creatinine, } \mathrm{mg} / \mathrm{dL} \\
(\mu \mathrm{mol} / \mathrm{L})\end{array}$ & $<1.2(110)$ & $\begin{array}{c}1.2-1.9(110- \\
170)\end{array}$ & $\begin{array}{c}2.0-3.4(171- \\
299)\end{array}$ & $3.5-4.9(300-440)$ & $>5.0(440)$ \\
\hline Urine output, mL/d & & & & $<500$ & $<200$ \\
\hline
\end{tabular}


dengan pediatric risk of mortality (PRISM) III, sistem penilaian untuk menilai tingkat keparahan penyakit. Perkiraan mortalitas pSOFA lebih baik dibandingkan sistem penilaian disfungsi organ lainnya (AUC, 0,88; 95\% CI, 0,86-0,91), $(\mathrm{p} \leq 0,02)$, dan memperlihatkan hasil yang sama dengan PRISM III (AUC, 0,88; 95\% CI, 0,86-0,91; $\mathrm{p}=0,94)$.

\section{Kesimpulan}

Hingga saat ini belum ada definisi dan sistem diagnosis standar untuk sepsis pada anak secara global. Konferensi internasional sepsis ketiga, menilai disfungsi organ pada sepsis dengan sistem SOFA, yang selanjutnya dilakukan adaptasi dan validasi sistem SOFA untuk pasien anak dengan pediatric SOFA (pSOFA) memperlihatkan hasil yang menjanjikan. Di Indonesia sesuai rekomendasi IDAI, penilaian disfungsi organ dalam mendiagnosis sepsis dilakukan dengan sistem PELOD-2.

\section{Daftar pustaka}

1. Kawasaki T. Update on pediatric sepsis. J Intensive Care 2017;5:47-59.

2. Hartman ME, Linde-Zwirble WT, Angus DC, Watson RS. Trends in the epidemiology of pediatric severe sepsis. Pediatric Crit Care Med 2013;14:686-93.

3. Weiss SL, Fitzgerald JC, Maffei FA, dkk. Discordant identification of pediatric severe sepsis by research and clinical definitions in the SPROUT international point prevalence study. Crit Care 2015;19:325.

4. Plunkett A, Tong J. Sepsis in children. BMJ 2015;350:3017.

5. Latief A, Chairulfatah A, Alam A, Pudjiadi A, Malisie RF, Hadinegoro SR. Pedoman nasional pelayanan kedokteran Ikatan Dokter Anak Indonesia: diagnosis dan tatalaksana sepsis pada anak. Indonesia: Badan penerbit Ikatan Dokter Anak Indonesia; 2016.h.1-47.

6. Turner D, Cheifetz I. Shock. Dalam: Kliegman R, Stanton B, Geme J, Schor N, penyunting. Nelson textbook of pediatrics. Edisi 20. Philadelphia: Elsevier; 2016.h.516-28.

7. Bochud PY, Calandra. Pathogenesis of sepsis: new concepts and implifications for future treatment. BMJ 2003;326:2626.
8. Cinel I, Opal SM. Molecular biology of inflammation and sepsis: a primer. Crit Care Med 2009;37:291-304.

9. Bone RC, Grodzin CJ, Balk RA. Sepsis: a new hypothesis for pathogenesis of the disease process. Chest 1997;112:235-43.

10. Funk DJ, Parrillo JE, Kumar A. Sepsis and septic shock: a history. Crit Care Clin 2009;25:83-101.

11. Bone RC, Sprung CL, Sibbald WJ: Definitions for sepsis and organ failure. Crit Care Med 1992;20:724-6.

12. Levy, MM, Fink MP, Marshall JC, Abraham E, Angus D, Cook D, dkk. International Sepsis Definitions Conference. 2001. SCCM/ESICM/ACCP/ATS/SIS International Sepsis Definitions Conference. Intensive Care Med 2003;29:530-8.

13. Rabello LS, Rosolem MM, Leal JV, Soares M, Lisboa T, Salluh JI. Understanding the PIRO concept: from theory to clinical practice - part 1. Rev Bras Ter Intensiva 2009;21:425-31.

14. Dellinger RP, Levy MM, Carlet JM, Bion J, Parker MM, Jaeschke R, dkk. Surviving Sepsis Campaign: International guidelines for management of severe sepsis and septic shock. Crit Care Med 2008;36:296-327.

15. Goldstein B, Giroir B, Randolph A; International Consensus Conference on Pediatric Sepsis. International pediatric sepsis consensus conference: definitions for sepsis and organ dysfunction in pediatrics. Pediatr Crit Care Med 2005;6:2-8.

16. El-Nawawy A, Mohsen AA, Abdel-Malik M, Taman SO. Performance of the pediatric logistic organ dysfunction (PELOD) and (PELOD-2) scores in a pediatric intensive care unit of a developing country. Eur J Pediatr 2017;176:849-55.

17. Gulla KM, Sachdev A. Illness severity and organ dysfunction scoring in pediatric intensive care unit. Indian J Crit Care Med 2016;20:27-35.

18. Singer M, Deutschman CS, Seymour CW, dkk. The third international consensus definitions for sepsis and septic shock (sepsis-3). JAMA 2016;315:801-10.

19. Seymour CW, Liu VX, Iwashyna TJ, dkk. Assessment of clinical criteria for sepsis: for the third international consensus definitions for sepsis and septic shock (sepsis-3). JAMA 2016;315:762-74.

20. Matics TJ, Sanches-Pinto N. Adaptation and validation of a Pediatric Sequential Organ Failure Asessment score and evaluation of sepsis-3 definitions in critically ill children. JAMA Pediatrics 2017;E1-9.

21. Gogia P, Koreti S, Patel GS. SOFA (Sequential Organ Failure Assessment) and PELOD (Pediatric Logistic Organ Dysfunction). Sch J App Med Sci 2015;3:1645-8. 